\title{
Value of Transthoracic Echocardiography in the Prediction of Post-spinal Anesthesia Hypotension
}

Ferdi Gülaştı ๑

Sevil Gülaştı ๑

Ibrahim Girgin $\odot$

Sinem Sarı $\odot$

\section{Transtorasik Ekokardiyografinin Spinal Anestezi Sonrası Hipotansiyonu Öngörmede Değeri}

Etik Kurul Onayı: Kütahya Sağlık Bilimleri Üniversitesi Klinik Araştırmalar Etik Kurul’undan onayı alınmıştır (2018/10-08 Ağustos, 2018).

Çıkar Çatışması: Çıkar çatışması yoktur.

Finansal Destek: Bu çalışma, herhangi bir fon tarafından desteklenmemiştir.

Hasta Onamı: Hastalardan aydınlatıımış onam alınmışıır.
Ethics Committee Approval: Approval was obtained from Kütahya Health Sciences University Clinical Research Ethics Board (2018/10-08 August, 2018).

Conflict of Interest: There is no conflict of interest.

Funding: This study was not supported by any funding.

Informed Consent: Informed consent was obtained from the patients.

Cite as: Gülaştı F, Gülaştı S, Girgin I, Sarı S. Value of transthoracic echocardiography in the prediction of post-spinal anesthesia hypotension development. GKDA Derg. 2020;26(4):228-35.

\section{ABSTRACT}

Objective: Spinal Anesthesia (SA) can lead to hypotension due to sympathic denervation, which causes a reduction in venous return to the heart as a result of peripheral vasodilation and redistribution of intravascular blood. Transthoracic Echocardiography (TTE) is a noninvasive and easy-to-use method to visualize cardiac reserve and functions. We aimed to evaluate whether parameters attained via transthoracic echocardiography are predictive of development of post-SA hypotension.

Method: Forty-two patients between the ages of 18 and 80, who would undergo inguinal hernia operation under SA, with ASA physical status I-II and had no clinically recognized cardiovascular disease, were included in the study. TTE was performed for each patient 30 minutes before the operation, and measurements were recorded along with the intraoperative hemodynamic parameters.

Results: There was a statistically significant difference between the medians of left ventricle enddiastolic diameter (LVEDD) (cm) according to the status of post-SA hypotension $(p=0.003)$ Accordingly, median LVEDD of patients who did not develop hypotension was significantly larger compared with that of those who had hypotension. Similarly, a statistically significant difference emerged between the medians of right ventricular (RV) tricuspid annular plane systolic excursion (TAPSE) (cm) showing RV global function according to the status of post-SA hypotension $(p=0.001)$. Accordingly, patients who did not have hypotension had a larger RV-TAPSE median compared with that of those who had hypotension. The difference between the medians of RV isovolumetric relaxation time (RV-IVRT), which is one of the indicators of RV diastolic functions was again statistically significant according to the status of post-SA hypotension ( $p=0.025)$.

Conclusion: TAPSE, RV-IVRT and LVEDD measured via preoperative TTE, can be significant parameters to predict the development of post-SA hypotension.

Keywords: spinal anesthesia, hypotension, transthorasic echocardiography, TAPSE, isovolumetric relaxation time, left ventricular end-diastolic diameter

Öz

Amaç: Spinal anestezi (SA), sempatik denervasyon nedeniyle hipotansiyona yol açabilir, bu da periferik vazodilatasyon ve intravasküler kanın yeniden dağılımının bir sonucu olarak kalbe venöz dönüsste azalmaya neden olur. Transtorasik ekokardiyografi (TTE), kalp rezervini ve fonksiyonların görselleştirmek için invaziv olmayan ve kullanımı kolay bir yöntemdir. TTE ile elde edilen parametrelerin SA sonrası hipotansiyon gelişimini belirleyici olup olmadığını değerlendirmeyi amaçladık. Yöntem: Kasık fıtığı ameliyatı geçirecek SA altındaki, ASA fiziksel durumu I-Il olan ve klinik olarak tanınan kardiyovasküler hastalığı olmayan 18-80 yas arası 42 hasta çalıșmaya dâhil edildi. Her hastaya ameliyattan $30 \mathrm{dk}$. önce TTE uygulandı ve intraoperatif hemodinamik parametrelerle birlikte ölçümler kaydedildi.

Bulgular: Spinal anestezi sonrası hipotansiyon durumuna göre sol ventrikül diyastol sonu çapının (LVEDD) (cm) medyanları arasında istatistiksel olarak anlamlı farklılık vardı ( $p=0.003$ ); buna göre, hipotansiyon gelişmeyen hastaların LVEDD medyanı, hipotansiyonu olanlara kıyasla anlamlı derecede daha büyüktü. Benzer olarak sağ ventrikül (RV) global fonksiyonunu gösteren RV triküspit anüler düzlem sistolik hareket (TAPSE) medyanları arasında istatistiksel olarak anlamlı bir fark ortaya çıtı. SA sonrası hipotansiyon durumuna göre ( $p=0.001$ ); buna göre, hipotansiyonu olmayan hastalar hipotansiyonu olanlara kıyasla daha büyük bir RV-TAPSE medyanına sahipti. Sağ ventrikül diastolik fonksiyonlarından biri olan izovolümetrik gevşeme zamanı (RV-IVRT) medyanları arasındaki fark, SA sonrası hipotansiyon durumuna göre yine istatistiksel olarak anlamlıydı $(p=0.025)$.

Sonuç: Preoperatif TTE ile ölçülen TAPSE, RV-IVRT ve LVEDD, post-SA hipotansiyon gelişimini tahmin etmek için önemli parametreler olabilir.

Anahtar kelimeler: spinal anestezi, hipotansiyon, transtorasik ekokardiyografi, TAPSE, izovolumet rik gevşeme zamanı, sol ventrikül diyastol sonu çap
Received/Geliş: 10.08 .2020

Accepted/Kabul: 16.11.2020

Published Online/Online yayın: 31.12.2020

Ferdi Gülaşt Bursa Sehir Hastanesi, Anesteziyoloji ve Reanimasyon Kliniği Bursa - Türkiye ferdigulasti@icloud.com ORCiD: 0000-0003-3774-7418

S. Gülaşt 0000-0002-7640-1295 Bursa Çekirge Devlet Hastanesi Kardiyoloji Kliniği Bursa, Türkiye

i. Girgin 0000-0002-1810-7098 Gediz Devlet Hastanesi Genel Cerrahi Kliniği Kütahya, Türkiye

S. Sarı 0000-0002-1467-8619 Adnan Menderes Üniversitesi Tıp Fakültesi, Anesteziyoloji Anabilim Dalı Aydın, Türkiye 


\section{INTRODUCTION}

Hypotension is a common hemodynamic side effect after spinal anesthesia (SA), which may lead to increased morbidity and mortality ${ }^{[1]}$. Since spinal anesthesia is easy to apply, it is preferred in lower abdominal, inguinal, urogenital, rectal, and lower extremity surgeries. SA causes changes in the arterial resistance, stroke volume, heart rate, cardiac output, and arterial blood pressure ${ }^{[2]}$. Arterial resistance and heart rate may decrease at a rate of $5-20 \%$ as a result of spinal anesthesia ${ }^{[2]}$. Arterial vasodilatation occurs as a result of the sympathetic nerve block, which develops with spinal anesthesia ${ }^{[3]}$. The level of the sympathetic block affects the change in the arterial resistance. The vasodilation in the sympathetic block in lower extremity that is limited in the lower or midthoracic area causes compensatory vasoconstriction in the upper extremity. In this case, the mean arterial resistance does not change ${ }^{[4]}$. However, when the sympathetic block affects the whole thoracic and lumbar region, compensatory vasoconstriction does not develop in the upper extremity, and as a result, basal blood pressure can decrease by more than $20 \%$, and the Mean Arterial Pressure (MAP) can decrease below $60 \mathrm{mmHg}{ }^{[4]}$. Transthoracic Echocardiography (TTE) is an easy and noninvasive imaging method providing information about cardiac reserves and functions. In this study, the relation between development of hypotension after spinal anesthesia and TAPSE, RV-IVRT, LVEDD observed with TTE was investigated.

\section{MATERIAL and METHODS}

\section{Patient population and study protocol}

The patients aged between 18 and 80 gave written their consents to participate in the study. The patients whose ASA (American Society of Anesthetists) physical statuses were I or II in preoperative evaluations, and those without any known heart disease were scheduled to undergo inguinal hernia surgery under spinal anesthesia, were included in the study. Patients under the age of 18 , with physical status of
ASA III and above, and any known heart disease, also cases that refused to participate were not included in the study.

The present study was conducted in Gediz State Hospital between September 2018 and August 2019 with 43 patients who agreed to participate in the study after the approval was received from the Clinical Research Ethics Board (Decision No: 2018/1008 August, 2018). After the oral and written consents of the patients were received, transthoracic echocardiography was performed on all patients 30 minutes before the surgery. However, in one patient, segmentary wall movement disorder was detected on TTE during the study. With the pre-diagnosis of coronary artery disease elective coronary angiography was recommended for this patient, and excluded from the study. The patients underwent spinal anesthesia using 25-G Quincke needle in the sitting position applied through L4-5 intervertebral space. Following injection of $10-12 \mathrm{mg} 0.5 \%$ hyperbaric bupivacaine into the subarachnoid space, the patients were kept in supine position. The sensory block level of the patients was achieved at the thoracic 8-10 level. Premedication was not given to the patients The amount of crystalloid solution to be given was calculated for the patients according to the preoperative fasting and hemorrhage status during the surgery. Mean arterial blood pressure (MABP) below $55 \mathrm{mmHg}$ or hypotensive attacks lasting more than 2 minutes were treated by using $5 \mathrm{mg}$ of intravenous ephedrine. The TTE measurements, findings, laboratory values, preoperative and intraoperative blood pressure, heart rate, and peripheral oxygen saturation measurements of the patients were recorded. Decreases in blood pressures at intraoperative 1st, 5 th and 10th minutes at a rate of $20 \%$ above basal systolic arterial blood pressure (SABP) measurements, $\mathrm{SAB}$ decreasing below $90 \mathrm{mmHg}$, and MABP decreasing below $60 \mathrm{mmHg}$ were considered as hypotension associated with SA.

\section{Echocardiography}

TTE was carried out for all patients by the same 
observer using Philips HD11 XE Echocardiography Device equipped with S4-2 Transducer (4-2 MHz frequency range) in the left lateral decubitus position. The values of all parameters were recorded by taking the mean values of the three cardiac cycle measurements. The measurement methods were carried out in line with American Echocardiography Association Guidelines. The M-Mode, 2-dimensional (2D) images, color, pulse and continuous-wave doppler and tissue Doppler measurements were obtained from all subjects who were compatible with standard echocardiographic application methods. The 2D left ventricle (LV) diameters, wall thickness, LV ejection fraction (EF) measurements, and LV systolic functions were evaluated in parasternal long axis view. LV end- systolic diameter and LV end- diastolic diameter (LVEDD) measurements were made with M-mode imaging vertical to the long axis of left ventricle at LV papillary muscle level. The early $(E)$ and late $(A)$ peak speeds, E/A ratio, deceleration time, and Isovolumetric relaxation time (IVRT) were measured in the transmittal flow to evaluate LV diastolic function. The peak systolic (SC), early diastolic (EC), and late diastolic (AC) mitral annular myocardial velocity of the LV septal and lateral walls were measured from the 4-chamber images with pulse wave Doppler.US.

The FAC, S' speed, TAPSE and TDI-derived myocardial performance index (MPI) were measured to evaluate the right ventricular (RV) systolic functions. The Tricuspid $E$ and $A$ wave rate, E/A ratio, E' speed were measured to evaluate diastolic function of RV. TAPSE was calculated by placing an M-mode cursor along the tricuspid ring, and measuring the longitudinal movement in the peak systole (Figure 1). The annular peak systolic speed (S), early $\left(E^{\prime}\right)$ and late $\left(A^{\prime}\right)$ peak annular diastolic rates, ejection time (ET), IVRT and Isovolumetric contraction time (IVCT) were measured from the TDI images. As a global estimate of both systolic and diastolic functions of RV, the TDI-sourced MPI was calculated as the sum of IVCT and IVRT, which were divided into ET (MPI = (IVRT + IVCT) / ET).

The patients were brought to the supine position, and the inferior vena cava (IVC) was imaged through the subxiphoid window. The cursor was placed on 1 $\mathrm{cm}$ distal of the hepatic vein IVC entry point, and the IVC diameter was monitored for 30 seconds in M-mode. The diameter of inferior vena cava was measured at the inspirium (IVCins) and expirium

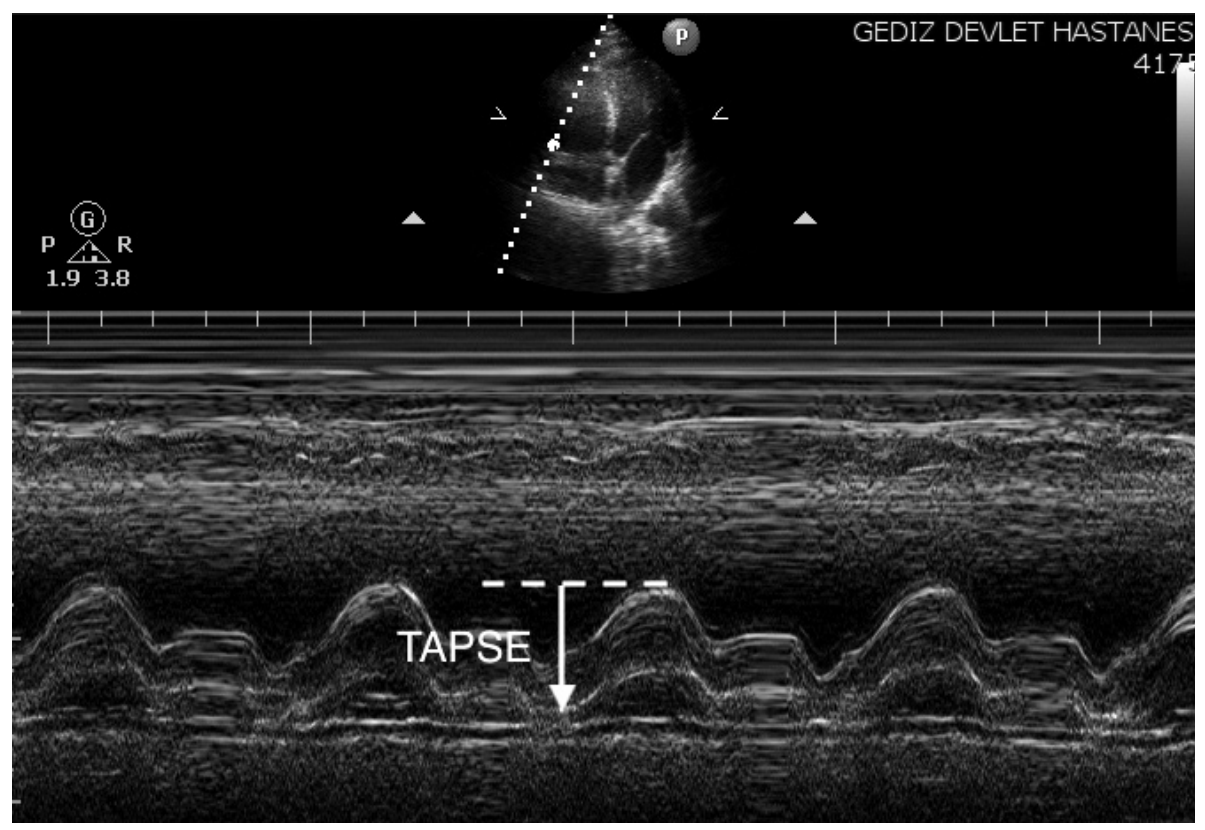

Figure 1. TTE imagine of TAPSE. 
(IVCexp) while the patient was breathing normally The inferior vena cava collapse ratio (IVC-CI) was calculated by using the IVC-CI = (IVCexp - IVCins) / IVCexp formula.

\section{Statistical Analysis}

The descriptive statistics were given in the table as mean \pm standard deviation and median for continuous variables in summarizing the data obtained in the study. The categorical variables were summarized as numbers and percentages. The normality of the numerical variables was checked with the Kolmogorov Smirnov Test. The Mann- Whitney $\mathrm{U}$ test was used in comparisons of two independent groups in case where numeric variables did not show normal distribution. Fisher's exact test was used in comparison of the differences between categorical variables.

Statistical analyses were made with Jamovi Project (2019) Jamovi (Version 1.0.5) [Computer Software] (retrieved from https://www.jamovi.org) and MedCalc Statistical Software Trial version (MedCalc Software bvba, Ostend, Belgium; http://www.medcalc.org; 2015) Programs; and the level of significance was taken as 0.05 ( $p$-value) in statistical analyses.

\section{RESULTS}

There were no statistically significant differences in demographic data such as gender, weight, age, ASA status, diabetes mellitus, hypertension and smoking between the two groups with and without hypotension after spinal anesthesia, and the distribution was similar ( $p>0.05$ ) (Table 1).

The LVEDD $(\mathrm{cm})$ of the patients with hypotension was higher at a significant level compared to the patients without hypotension after SA $(p=0.003)$. Similarly, the TAPSE $(\mathrm{cm})$ of the patients without hypotension was significantly higher than those with hypotension ( $p=0.001)$. The RV-IVRZ of the patients with hypotension was higher at significant levels compared to the patients without hypotension $(p=0.025)$ (Table 2).

When the other parameters were examined, no statistically significant differences were detected between heart rate, LV, LV diastolic function, RV, left and right atrium, IVCins, IVCexp, IVC-Cl, pulmonary artery pressure $(\mathrm{mmHg})$, cardiac output, valves and maintenance parameters in terms of hypotensive conditions after spinal anesthesia $(p>0.05)$ (Table 2).

The cut-off values according to TAPSE, IVRZ and LVEDD variables to distinguish the patients with and without hypotension after spinal anesthesia are shown in Table 3 and Figure 2.

Tablo 1. Demografik özellikler, ek hastalıklar ve ilaç kullanımı.

\begin{tabular}{|c|c|c|c|c|}
\hline & & Yes $(n=14)$ & No $(n=28)$ & p \\
\hline Gender & $\begin{array}{l}\text { Male } \\
\text { Female }\end{array}$ & $\begin{aligned} 13 & (92.86) \\
1 & (7.14)\end{aligned}$ & $\begin{array}{c}27(96.43) \\
1(3.57)\end{array}$ & 0.999 \\
\hline Weight & & $71.33 \pm 12.93$ & $70.8 \pm 9.19$ & 0.962 \\
\hline Age & & $56.62 \pm 11.18$ & $51.23 \pm 11.59$ & 0.259 \\
\hline ASA & $\begin{array}{l}1 \\
2\end{array}$ & $\begin{array}{c}10(71.43) \\
4(28.57)\end{array}$ & $\begin{array}{l}18(64.29) \\
10(35.71)\end{array}$ & 0.738 \\
\hline DM (Positive) & & $1(7.14)$ & $1(3.57)$ & 0.999 \\
\hline HT (Positive) & & $2(14.29)$ & $4(14.29)$ & 0.999 \\
\hline \multicolumn{5}{|l|}{ Smoking } \\
\hline & $\begin{array}{l}\text { Yes } \\
\text { No }\end{array}$ & $\begin{array}{c}3(21.43) \\
11(78.57)\end{array}$ & $\begin{array}{c}3(10.71) \\
25(89.29)\end{array}$ & 0.383 \\
\hline
\end{tabular}

DM: Diabetes mellitus HT: Hypertension 


\begin{tabular}{|c|c|c|c|}
\hline & \multicolumn{2}{|c|}{ HYPOTENSION } & \multirow[b]{2}{*}{$\mathbf{p}$} \\
\hline & Yes & No & \\
\hline \multicolumn{4}{|l|}{ Left Ventricle } \\
\hline Diastole end diameter $(\mathrm{cm})$, median [IQR] & $4.34[4.09-4.7]$ & $4.9[4.59-5.16]$ & 0.003 \\
\hline Range mean -------------> & 13.5 & 25.5 & \\
\hline Systole end diameter $(\mathrm{cm})$ & $3.39[2.98-3.66]$ & $3.61[3.35-3.89]$ & 0.069 \\
\hline EF (\%) & $63.5[60-67]$ & $64[62-69]$ & 0.300 \\
\hline Stroke Volume & 74.5 [64-89] & $70.5[64-90.5]$ & 0.947 \\
\hline \multicolumn{4}{|l|}{ Right ventricle } \\
\hline $\mathrm{S}(\mathrm{cm} / \mathrm{s})$ & $0.14[0.12-0.15]$ & $0.13[0.12-0.19]$ & 0.654 \\
\hline TAPSE (cm), median[IQR] & $2[1.88-2.26]$ & $2.36[2.21-2.67]$ & \multirow{2}{*}{0.001} \\
\hline Range mean --------> & 12.61 & 25.95 & \\
\hline FAC & $38.4[32.4-49.6]$ & $36.85[32.35-47.75]$ & 0.603 \\
\hline MPI & $0.77[0.68-0.92]$ & $0.78[0.63-0.85]$ & 0.640 \\
\hline IVRT. median [IQR] & $0.13[0.1-0.14]$ & $0.1[0.09-0.12]$ & \multirow{2}{*}{0.025} \\
\hline Range mean ------------> & 27.46 & 18.52 & \\
\hline IVCT & $0.08[0.07-0.09]$ & $0.08[0.07-0.09]$ & 0.778 \\
\hline ET & $0.26[0.24-0.29]$ & $0.26[0.22-0.28]$ & 0.621 \\
\hline Inf. v. Cava diameter "Ins" ( $\leq 2.1 \mathrm{~cm})$ & $0.89[0.75-1.09]$ & $0.92[0.8-1.13]$ & 0.362 \\
\hline Inf. v. Cava diameter “Exp" ( $\mathrm{N} \leq 2.1 \mathrm{~cm})$ & $1.51[1.21-1.61]$ & $1.56[1.35-1.72]$ & 0.544 \\
\hline Collapse Ratio ( $\mathrm{N}>50 \%$ ) & $33[28-45]$ & 37 [29-44] & 0.862 \\
\hline Systolic Pulmonary Artery Pressure $(\mathrm{mmHg})$ & $17.5[15-24]$ & $17[15-25.5]$ & 0.809 \\
\hline Cardiac Output & $4.5[4.2-4.8]$ & $5.1[4.4-6.15]$ & 0.186 \\
\hline
\end{tabular}

EF: Ejection Fraction, S: Systolic speed TAPSE: Tricuspid Annular Plane Systolic Excursion, FAC: Fractional area change, MPI: Myocardial Performance Index, IVRT: Isovolumetric Relaxation Time, IVCT: Isovolumetric Contraction Time ET: Ejection Time

The rate of having hypotension in patients with TAPSE distance of $\leq 2.05 \mathrm{~cm}$ was higher than the patients with TAPSE distance of $>2.05 \mathrm{~cm}(p=0.001)$.

\section{DISCUSSION}

After spinal anesthesia, the decrease in SAB at and above $20 \%$ in the first 10 minutes or the decrease in MAP below $60 \mathrm{mmHg}$ was associated with spinal anesthesia. In our study, the purpose was to predict hypotension associated with spinal anesthesia using parametres of TAPSE, RV-IVRT, LVEDD estimated with real-time TTE and other parameters measured prior to SA in predicting hypotension after SA. As a result of our study, the LVEDD ( $p=0.003)$; TAPSE ( $p=0.001)$, and RV-IVRT ( $p=0.025)$ measurements were found to be significant in predicting the hypotension after spinal anesthesia in patients who underwent inguinal hernia surgery in the present study. No relations were detected between IVC diameters, IVC-CI, and other echocardiographic parameters and hypotension after spinal anesthesia.

Hypotension that is associated with spinal anesthesia is also associated with the sensory block level. If the block level is below L-3, the hemodynamic change is minimal ${ }^{[5]}$. In the present study, the sensory block levels were monitored as thoracic 8-10 in both groups, and no differences were detected between the groups as for frequency of hypotension..

It is known that right ventricular systolic dysfunction has prognostic value in various pathological cases. Evaluating RV function with echocardiography is very 
Table 3. ROC analysis results based on TAPSE. IVRZ and Diastole end diameter variables of hypotension positivity after Spinal Anesthesia.

\begin{tabular}{|c|c|c|c|c|c|c|}
\hline & AUC & Sensitivity & Specificity & Cut Off & $\% 95$ GA & $\mathbf{p}$ \\
\hline TAPSE & 0.818 & 57.14 & 92.86 & $\leq 2.05$ & $0.668-0.920$ & $<0.0001$ \\
\hline IVRZ & 0.713 & 50 & 92.86 & $>0.128$ & $0.553-0.842$ & 0.0256 \\
\hline LV Diastole end diameter & 0.786 & 92.86 & 57.14 & $\leq 4.78$ & $0.632-0.897$ & 0.0001 \\
\hline
\end{tabular}

TAPSE: Tricuspid Annular Plane Systolic Excursion IVRT: Isovolumetric Relaxation Time LV: Left Ventricle

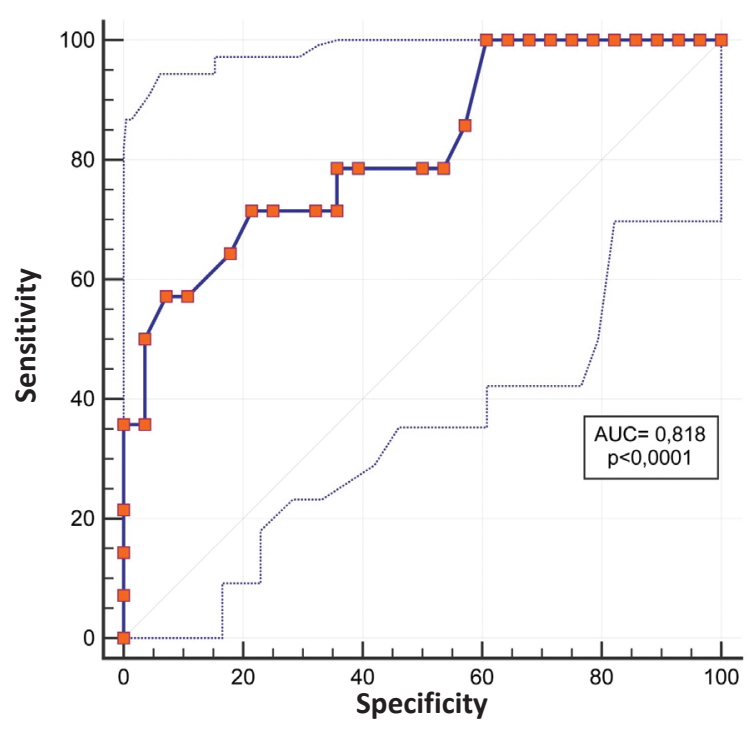

Figure 2. ROC analyse of TAPSE.

difficult because of the complex geometry of RV. Although RV function was only evaluated visually for many years, as a result of recent studies, guidelines were published by the American Society of Echocardiography. In this respect, in case of the presence of one of the following criteria as: $S^{\prime}<10 \mathrm{~cm} /$ S, TAPSE $<16 \mathrm{~mm}$, RVFAC $<35 \%$ or R-MPI (Tissue Doppler) $>0.55$ abnormal RV function should be suspected. Normal and abnormal functions are distinguished more reliably by combining more than one measurements of RV function. TAPSE is a parameter that can be easily measured by apex-basal shortening providing specific information about global RV function. It is an easier criterion to measure and is less dependent on optimal image quality compared to other RV function measurements ${ }^{[6]}$. Low TAPSE is not very common; however, it was measured in some people without heart disease because of mea- surement errors, diagnostic misclassifications, and excessive ends of the normal spectrum. In a study conducted by Ueti et al., the authors compared the radionuclide angiography method, which is the gold standard for TAPSE and RV ejection fraction to evaluate the right ventricular functions, and found almost equal specificity and sensitivity for the two methods [7]. Eckhardt Schmid et al. showed that TAPSE value being $<1.8 \mathrm{~cm}$ was an independent determinant to prevent intraoperative resuscitation and mortality in cardiac surgery patients undergoing emergency pulmonary embolectomy ${ }^{[8]}$. In the present study, it was found that TAPSE was significantly lower in patients who developed hypotension after spinal anesthesia compared to those who did not $(<2.05 \mathrm{~cm})$. Measuring TAPSE with echocardiography can be guiding in predicting hypotension in patients before spinal anesthesia.

It was shown in several studies that the diameter of the inferior vena cava and IVC collapse Index can be used to detect hypovolemia ${ }^{[9]}$. It is predicted that SA-related hypotension might develop in the case of hypovolemia. In the study conducted by Theodosius Saranteas et al., it was concluded that the dIVCmaxIVCCI ratio was the determinant of SA-related hypotension in elderly patients ${ }^{[10]}$. Unlike this study, in the study that was conducted by Mačiulienè $A$ et al., it was determined that the decrease in IVC diameters and the increase in IVC-Cl did not predict hypotension under SA in patients undergoing elective knee joint replacement surgery ${ }^{[11]}$. In our study, no relation was detected between SA-related hypotension and IVC diameters and IVC-CI. Again, no relations were shown between aortic current speeds, peak velocity values, diameter, and volume of atri- 
ums, diameter, and volume of RV which are among the parameters that might change with volume status in transthoracic echocardiography. However, a positive correlation was detected between LVEDD $(<4.79 \mathrm{~cm})$, which might change in the case of hypovolemia, and the hypotension that developed after spinal anesthesia.

The right ventricular isovolumetric relaxation phase is the time relapsed between the losure of the pulmonary valve and opening of the tricuspid valve. Like the use of RV-IVRT, RV is also used as the indicator of diastolic dysfunction ${ }^{[12]}$. It was proven that RV-IVRT is shorter than LV-IVRT [13]. In previous studies, a strong correlation was shown between systolic Pulmonary Artery Pressure (PAB) and RV-IVRT measured invasively ${ }^{[14,15]}$. A correlation was shown between the corrected IVRT and the mean PAB measured with echocardiography especially in patients without severe RV dysfunction ${ }^{[16]}$. In our study, we showed that RV-IVRT ( $>0.128$ seconds) was guiding in predicting hypotension after spinal anesthesia.

There are some studies aimed at finding corelation between the central venous pressure and TAPSE [17]. However, so far, it has not been recommended to use TAPSE RV as a measurement of its preload or liquid sensitivity. TAPSE is an echocardiography parameter, which can be used in everyday practice with its easy measurement and unaffected image quality. Hypotension after spinal anesthesia has been often associated with hypovolemia. For this reason, as a result of our study, TAPSE may be a new idea in predicting hypovolemia in patients with normal cardiac functions. Besides, in patients with normal cardiac functions, it may be considered that there may be cardiac limits in compensating physiological effects of spinal anesthesia. For this purpose, further studies are required to support the use of TAPSE to predict hypotension after spinal anesthesia and to evaluate its relation with hypovolemia.

\section{Conclusions}

As a conclusion, we believe that as an indicator of RV global function TAPSE, which is estimated with preoperative transthoracic echocardiography, is easy to measure and it is effective in predicting hypotension developing after spinal anesthesia. However our study findings should be supported with new studies.

\section{REFERENCES}

1. Lawick M, Malek A, Antczak D, Wajlonis A, Owczuk R. Non-invasive haemodynamic measurements with Nexfin predict the risk of hypotension following spinal anaesthesia. Anaesthesiol. Intensive Ther. 2015;47: 403-8. https://doi.org/10.5603/AIT.2015.0048

2. Esener Z. Lokal/Bölgesel Anestezi, Klinik Anestezi, Logos Yayıncılık, İstanbul 1991. S: 363-428

3. Hartmann B, Junger A, Klasen J, et al. The incidence and risk factors for hypotension after spinal anaesthesia induction: An Analysis with Automated Data Collection. Anesth Analg 2002;94(6):1521-9. https://doi.org/10.1213/00000539-200206000-00027

4. Mark JB, Steele SM. Cardiovascular effects of spinal anesthesia. Int Anesthesic Clin. 1989;27:31-9. https://doi.org/10.1097/00004311-198902710-00007

5. Veering B. Physiological Aspects of Central Blockade Euroanaesthesia Austria; Vienna, Austria: 2005. pp. 23-27.

6. Lee S, Kamdar F, Madlon-Kay R, Boyle A, Colvin-Adams $M$, Pritzker $M$. et al. Effects of the HeartMate II continuous-flow left ventricular assist device on right ventricular function. J Heart Lung Transplant. 2010;29:209-15. https://doi.org/10.1016/j.healun.2009.11.599

7. Ueti OM, Camargo EE, Ueti Ade A, de Lima-Filho EC, Nogueira EA. Assessment of right ventricular function with Doppler echocardiographic in-dices derived from tricuspid annular motion: comparison with radionuclide angiography. Heart 2002;88:244-8. https://doi.org/10.1136/heart.88.3.244

8. Schmid E, Hilberath JN, Blumenstock G, Shekar PS, Kling S, Shernan SK, Rosenberger P, Nowak-Machen M. Tricuspid annular plane systolic excursion (TAPSE) predicts poor outcome in patients undergoing acute pulmonary embolectomy. Heart Lung Vessel. 2015;7(2):151-8. PubMed PMID: 26157741; PubMed Central PMCID: PMC4476769

9. Zhang Z, Xu X, ye $s, \mathrm{Xu} L$ : Ultrasonographic measurement of the respiratory variation in the inferior vena cava diameter is predictive of fluid responsiveness in critically ill patients: systematic review and metaanalysis. Ultrasound Med Biol 2014; 40:845-53 https://doi.org/10.1016/j.ultrasmedbio.2013.12.010

10. Saranteas T, Spiliotaki H, Koliantzaki I, Koutsomanolis D, Kopanaki E, Papadimos T, Kostopanagiotou G. The Utility of Echocardiography for the Prediction of Spinal Induced Hypotension in Elderly Patients: Inferior Vena Cava Assessment Is a Key Player. J Cardiothorac Vasc Anesth. 2019 Sep;33(9):2421-2427.doi: 10.1053/j. jvca.2019.02.032. Epub 2019 Feb 22. PubMed PMID: 30904260. 
https://doi.org/10.1053/j.jvca.2019.02.032

11. Mačiulienè A, Gelmanas A, Jaremko I, Tamošiūnas R, Smailys A, Macas A. Measurements of Inferior Vena Cava Diameter for Prediction of Hypotension and Bradycardia during Spinal Anesthesia in Spontaneously Breathing Patients during Elective Knee Joint Replacement Surgery. Medicina (Kaunas). $2018 \mathrm{Jul}$ 12;54(3). pii: E49. PubMed PMID: 30344280; PubMed CentralPMCID: PMC6122100.

https://doi.org/10.3390/medicina54030049

12. Otto C. Echocardiographic evaluation of left and right ventricular systolic function. In: Otto C. Textbook of clinical echocardiography. 2nd ed. Philadelphia: W.B. Saunders, 2000: 127.

13. Otto C. Echocardiographic evaluation of ventricular diastolic filling and function. In: Otto C. Textbook of clinical echocardiography. 2nd ed. Philadelphia: W.B. Saunders, 2000: 144.

14. Bréchot N, Gambotti L, Lafitte S, Roudaut R. Usefulness of right ventricular isovolumic relaxation time in predicting systolic pulmonary artery pressure. Eur J
Echocardiogr. 2008 Jul;9(4):547-54. https://doi.org/10.1093/ejechocard/jen121

15. Ernande L, Cottin V, Leroux PY, Girerd N, Huez S, Mulliez $A$, et al. Right isovolumic contraction velocity predicts survival in pul- monary hypertension. J Am Soc Echocardiogr. 2013;26(3):297-306. https://doi.org/10.1016/j.echo.2012.11.011

16. Parsaee M, Ghaderi F, Alizadehasl A, Bakhshandeh H. Time from the Beginning of the Right Ventricle Isovolumetric Contraction to the Peak of the S Wave: A New TDI Indicator for the Non-Invasive Estimation of Pulmonary Hypertension. Res CardiovasAc Med. 2016 Jul 20;5(3):e26494.

https://doi.org/10.5812/cardiovascmed.26494

17. Hongmin Z., Xiatoting W., Xiukai C., Qing Z. and Dawei L. Tricuspid annular plane systolic excursion and central venous pressure in mechanically ventilated critically ill patient; Cardiovascular Ultrasound 2018 Aug 7;16(1):11.

https://doi.org/10.1186/s12947-018-0130-2 